\title{
Speech Function of Teachers and Students' Utterances in Classroom Interaction at the Elementary School
}

\author{
Rafika Nur Rahman \\ English Applied Linguistics \\ Universitas Negeri Medan \\ Medan, Indonesia \\ fikarahman24@gmail.com
}

\author{
Rahmad Husein \\ Universitas Negeri Medan \\ Medan, Indonesia
}

\author{
Meisuri \\ Universitas Negeri Medan \\ Medan, Indonesia
}

\begin{abstract}
Speech function is an exchange communication between speaker and listener where the speaker adopts a speech functional role and signs the addressee a complementry role. This research discusses a case study of speech functions are used by teachers and students in the classroom interaction and how the speech function are realization of Mood. This research was conducted in a qualitative research. The participant of this study is teachers and students' utterances in classroom interaction of elementry school. The Instrument of collecting the data the researcher used audio recorder and observation sheet.The findings showed that the types of speech functions found in teacher and studentsutterances in classroom interactions are statement, question, command, offer, and minor. In which statement is more often used by teacherinthe interaction with the students, followed byquestion, command, offer and minor. Therefore,
\end{abstract}

Keywords-Speech Functions, Teachers and Students, Utterances

\section{INTRODUCTION}

Language has a wider sense than speech because language refers to speaking, writing and gesturing. Linguistics only deals with spoken language (speech) and written language. While speech is always spoken language, Robins (1981: 78) defines speech as follows: "one human being, by movements beginning at his diaphragm and involving 'various parts of his chest, throat, mouth, and nasal passages creates disturbances in the air around him, which within a limited distances from him have a perceptible effect on the ear-drums and through them on the brains of other people, and the hearer can, if they belong to the same language community, respond to these disturbance, or noises, and find them meaningful". Speech function itself can be divided into four kinds : statement, question, command, and offer. Halliday (1994: 68-69)divides the four basic speech functions: statement, question, offer, and command.

Halliday and Matthiesen (2014: 97) said that Mood is the major interpersonal system of the clause; it provides interactants involved in dialogue with the resources for giving or demanding a commodity, either information or goods and services in other words, with the resources for enacting speech functions (speech acts) through the grammar of the clause: statements (giving information), questions (demanding information), offers (giving goods- $\&$-services), and commands (demanding goods and services).

The four speech function are realize in Mood. In other words, with reference to the semiotic system the speech function is analogous to meaning and the Mood is to expression. In their unmarked or congruent representations the basic or proto speech functions of statement, question, and commandare respectively realized or expressed by declarative, intterogative,and imperative Moods. When the teacher talk in the classroom, there are role of speech function in giving and sharing information for their students. They use statement in giving information for their students or they can use question to demand information from the students.

But in fact, in this school the teachers used incongruent sentences in delivering knowledge to students. Teachers realized the speech function incongruently, it makes the students feel misunderstanding with what the teachers said and it makes the teacher intention can't do by students because they don't understand what the teachers means. The examples of incongruent utterances that usually used by teachers in the classroom can be seen as follow:

S: "Excuse me Miss, I'm late"(S : congruent/declarative)

T: "I want to know what time is it now." (S :

incongruent/interrogative)

S: "it is 08.15 Miss"( $\mathrm{S}$ : congruent/declarative).

Based on the utterances above, it can be analyzed the realization of mood are : T : "What time is it now?" (Speech Function: Question, Speech Function realized in Mood by using Imperative).

\begin{tabular}{|c|l|l|c|c|c|c|}
\hline$I$ & $\begin{array}{l}\text { Want to } \\
\text { know }\end{array}$ & what & Time & is & it & Now \\
\hline S & F/P & Adj/Wh & S & F/P & Comp. & Adj \\
\hline \multicolumn{2}{|c|}{ Mood } & Residu & \multicolumn{2}{|c|}{ Mood } & \multicolumn{2}{|c|}{ Residu } \\
\hline
\end{tabular}

The situation of that utterances happened because of the student came late to class. Actually the responses ofthe teacher is please come in (statement/declarative). It shows that the teacher didn't say what she really means to say directly. Her utterances may be ended to ambiguity. As the teacher said that "I want to know what time is it now" is categorized as 
questionbut the realization by usingdeclarative. However in this case, the teacher did not ask about the time but she was angry with the stundent. The teacher was asking to the students "don't come late again!" but satirize to the students by asking the time at that moment. But the student cannot understand the message of language, is it showing demanding information or command. So the student was confuse what really the teacher's said to him. Therefore, the speech functions which role to be understood easily to the student become difficult and get misunderstanding based on the above case.

Therefore, we are as the researcher will use Halliday's theory that stated, "Speech functions are divided into four aspects, they are statement, offer, command, and question". It is used for analyzing the teachers and students' utterances in classroom interaction realization to Mood types in this study. Related to background of the study, problem of the study are to identify the types of speech functions are used by teachers and students' in the classroom interaction.

\section{LITERATURE REVIEW}

\section{A. Definition of Speech Function}

Speech function is an exchanged communication between speaker and listener where the speaker adopts a speech functional role and assigns the addressee a complementary role. Halliday (1994:69) states that when exchanging and expressing ideas, human being perform two roles namely giving and demanding, for the commodity such as information and goods or services. In systemic functional linguistic (SFL), it is named speech function.

Speech function is a way of someone delivers ideas in communication to make listener understand the ideas well. Speech function itself can be divided into four kinds: statement, question, command, and offer. It is related to Halliday (1994: 68-69) divides the four basic speech functions: statement, question, offer, and command.

\section{B. The Four Basic Speech Function}

Halliday (1994: 68-69) divides the four basic speech functions : statement, question, offer, and command. The four basic speech functions are related to both the exchanged process. They are :

\section{Offer}

The speaker gives the hearer some goods or some services and the speaker inherently inviting the hearer to receive those goods and services.

Example: "Would you like to help me?"

\section{Command}

The speaker demand the hearer some goods or some service and the hearer are thereby invited to give that service or provide the goods.
Example : "Close the door!"

\section{Statement}

The speaker gives information to hearer, and invites the hearer to receive that information.

Example: "I went to Jakarta"

4. Question

The speaker demands the hearer some information and the hearer are thereby invited to give that service or provide the goods. A question may be either a linguistic expression used to make a request for information, or else the request itself made by such an expression. This information is provided with an answer. Questions are normally put or asked using interrogative sentences. Example: "Did yo go to Jakarta?"

From the four speech function previously, they are classfield as semantic in nature. They find their realizations in Mood which is an aspect of interpersonal meaning at the level of lexicogrammar (Halliday 1994). In their congruent representations the speech function of statement, question, and command are realized by declarative, interrogative and imperative. However, the speech function of offer does not have an unmarked representation of Mood; rather it is potentially coded by one of the four speech functions. In English, the unmarked realizations of the speech functions can be summarized in the following figure.

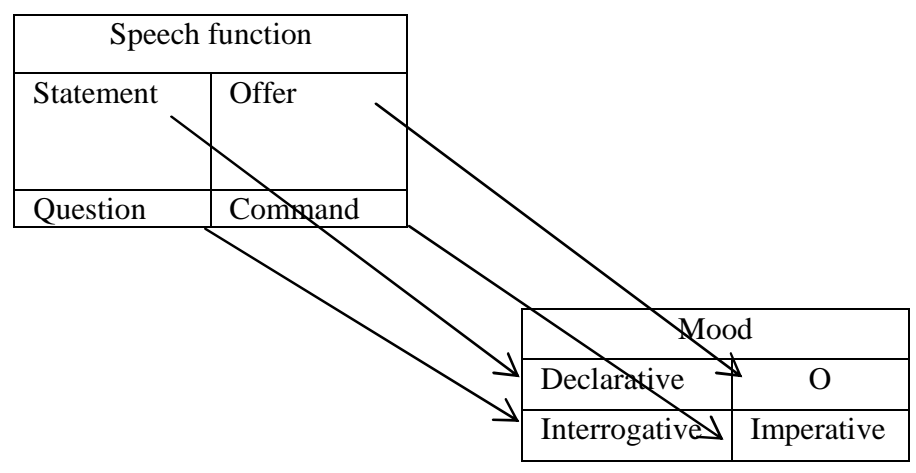

Fig. 1. Unmaked Realization of Speech Functions in Mood

\section{Mood}

To better understand the relationship of the language users within the language, further interpersonal analysis needs to be done within the MOOD system. In this system, discourse is broken down by categorizing lexical items on the basis of the clause into specific categories: Subject, Finite, Predicator, Compliment, and Adjunct.

Halliday and Matthiessen (2004:115-124) state that within the MOOD system, each feature accomplishes something different within the scope of interpersonality. The Subject is the entity that is responsible for the clause's validity and is represented by a nominal group.

The Finite element allows the clause to become "arguable" by placing it within a reference of time or personal position, which is seen in the tense, polarity, or modality. The Predicator represents the process happening within the clause, represented by a verbal group. The Complement is a nominal 
group that could potentially become the Subject and carry the responsibility, and an Adjunct is usually either an adverbial group or a prepositional phrase that can represent speaker/writer opinion or can add additional information, but is not necessary to understand the overall meaning of the clause.

The pattern below is what it is called the congruent one that is involving an unmarked association between discourse function and grammatical form.

\section{TABLE 1 SPEECH FUNCTION AND TYPICAL MOOD IN CLAUSSE}

\begin{tabular}{lc}
\hline Speech Function & $\begin{array}{c}\text { Typical Mood in } \\
\text { Clause }\end{array}$ \\
\hline Statement & Declarative \\
Question & Interrogative \\
Command & Imperative \\
Offer & Modulate \\
& interrogative
\end{tabular}

Eggins and Slade (1997: 183)

Sometimes there are many incongruent realizarions of speech functions that can be found in informal dialogue. These phenomena occur when a speech function is not realized by the predicated mood type; it can be seen it from the table below:

TABLE 2 CONGRUENT AND INCONGRUENT REALIZATION OF SPEECH FUNCTION

\begin{tabular}{lll}
\hline $\begin{array}{l}\text { Speech } \\
\text { Function }\end{array}$ & $\begin{array}{l}\text { Congruent } \\
\text { Clause Mood }\end{array}$ & $\begin{array}{l}\text { Incongruent } \\
\text { Clause Mood }\end{array}$ \\
\hline Statement & Declarative & $\begin{array}{l}\text { Tagged } \\
\text { declarative } \\
\text { Question }\end{array}$ \\
Command & $\begin{array}{l}\text { Intterogative } \\
\text { Imperative }\end{array}$ & $\begin{array}{l}\text { Modulated } \\
\text { Declarative } \\
\text { modulated }\end{array}$ \\
Offer & $\begin{array}{l}\text { Modulated } \\
\text { interrogative } \\
\text { declarative } \\
\text { Imperative, } \\
\text { declarative }\end{array}$ \\
\hline
\end{tabular}

Eggins and Slade (1997:184)

From the Table 1.2, it can be explained that when the speech function is realized in statement, the mood should be declarative. It is called as congruent clause mood. But when the speech function is realized in statement, the mood occur tagged declarative, it is called as incongruent clause mood. It also occurs in the speech function in question, command, and offer.

\section{RESEARCH METHOD}

This research will be conducted in a qualitative research. According to toBogdan and Biklen (1992: 30), a qualitative method has a natural setting as the direct source of data.This research was conducted by applying a descriptive qualitative method by Bogdan and Biklen's theory(1998: 4)conclude five characteristics of qualitative research namely:1)Naturalistic, qualitative research has actual 'setting' functions as the data source and the analyst is the main instrument,2) descriptive in nature, the data collected take the form of words or pictures, 3) concern with process, the process is more important than the result, 4) the data are analyzed inductively, and 5) 'the meaning' is the main focus. The data of this study are clauses consist of speech functions used by teachers and students' in classroom interaction which speech function realized in mood. The clauses are uttered in English language and will be concerned on linguistic features. Furthermore, data source of this study were teachers and sudents' who teach in SD Panca Budi Medan.

The technique of data collection is observation technique. The instrument of the data collection was audio recorder and observation sheet. The data are collected by recording the conversation of the teachers and studentsutterances in classroom interaction. Then, researcher transcribes the utterances from the conversation, and analyzed them through speech function theory.

The data will be analyzed by interactive model classified officially Miles, Huberman \& Saldana[12] In this analysis, it is by ongoing analysis and after collecting the entire the data (Miles, Huberman \& Saldana, 2014). Purpose an analysis as three concurrent flowed of activity: (1) data condensation, (2)data display, and (3) conclusion drawing / verification.

\section{RESULT AND DISCUSSION}

After analyzing the data, the data are classified based on the types of speech functions. There are four types of speech functions of male and female lecturers and one new type that have been found in the classroom interactions. They are statement, question, command, offer and minor, see in Table 2

TABLE 3. TYPES OF SPEECH FUNCTION OF TEACHERS AND STUDENTS UTTERANCES IN CLASSROOM INTERACTION

\begin{tabular}{l|c|c}
\hline Specch Function & $\begin{array}{c}\text { Clauses of Teachers } \\
\text { Utterances }\end{array}$ & Percentage \\
\hline Offer & 22 & 5.3 \\
\hline Command & 64 & 14.6 \\
\hline Statement & 194 & 47.5 \\
\hline Question & 108 & 26.7 \\
\hline Minor & 5 & 4.6 \\
\hline Total & $\mathbf{3 8 8}$ & $\mathbf{1 0 0}$ \\
\hline
\end{tabular}

Based on table 3 it can be describe that 22 ( 5,3\%) as offer, $64(14,6 \%)$ as command, $194(47,5 \%)$ as statement, 109 ( $26,7 \%)$ as question, $5(4,6 \%)$ as minor. It means that most of teacher used statement to demands the students some information.

Based on the table, all types of speech functions occurred in the classroom interactions. It was also found a new type of speech function that is minor of response (acceptance). Minor of response (acceptance) was used teachers. Meanwhile, the 
dominant type of speech function which was used by teachers is statement. It was different from other research who did not find minor of response (type of acceptance) used by students educators.

\section{CONCLUSION}

In this research, the researchers found out 4 types of speech function in classroom interaction such as offer, command, statement, and question realized in mood. The dominant speech functions expressed by the teachers and students' utterances are: speech function (statement ) which is shown on the table and they are 194 data. It means most of the characters expressed speech function (statement) to show their curiosity and to get the knowledge rather than use other words or sentences such as explaining the situation or offering a repair as indirectly.
The result found that speech functions expressed by theteachers and students' utterances depend on the context, whereas there are some factors influenced in classroom interaction.

\section{REFERENCES}

[1] Bogdan, R.C and S.K. Biklen. 1992. Qualitative Research for Education. An Introduction to Theory and Methods. Boston: Allyn and Bacon.

[2] Eggins, S, 2005. An Introduction to Systemic Functional Linguistic, London: Continuum.

[3] Eggins, S and Slade, T. 1997. An Introduction to Systemic Functional Linguistics. Covent Garden. London.

[4] Halliday, M.A.K. 2004. An Introduction to Functional Grammar. London: Edward Arnold.

[5] Halliday, M.A.K \& Matthiessen, C.M.I.M. 2004. An Introduction to Functional Grammar. London: Routledge. 